\title{
Evaluation of the Protective Roles of Synthetic Zeolite on Some Physiological and Biochemical Parameters after Cadmium Toxicity of Crayfish (Procambarus Clarkii) Mohamed M.A. Shahat ${ }^{1 \& 3}$, Maged M.A. Fouda ${ }^{1 \& 4}$, Hussein A. A. Sultan ${ }^{1}$, and Ibrahim O. Ali ${ }^{2 \& 4}$ \\ 1.Department of Zoology, Faculty of Science, Al-Azhar University (Assiut - Egypt), 2.Chemistry Department, Faculty of Science, Al-Azhar University (Cairo- Egypt), 3. Department of biology, Jazan University, Jazan, Kingdom Saudi Arabia, \\ 4. Department of Biology, Jouf University, Sakaka, Kingdom Saudi Arabia. \\ Correspondence: Mohamed M.A. Shahat, Email: shahat_egy@yahoo.com
}

\begin{abstract}
Background: the release of heavy metals into the environment through industrial effluents is a major concern, worldwide and removal of such pollutants has been a great concern during the last decades. Heavy metals are not biodegradable and tend to be accumulated in organisms and cause numerous diseases and disorders. Aim of the Work: this study evaluated the protective role of synthetic zeolite against cadmium toxicity of freshwater crayfish (Procambarus clarkii). Patients and Methods: the crayfish was divided into six groups (36 individual in each group), the first group was used as a control group, the second group was exposed to a dose of $(50 \mu \mathrm{g} / \mathrm{L})$ cadmium chloride for 45 days, the third group exposed to a dose of $(50 \mu \mathrm{g} / \mathrm{L})$ cadmium chloride for 45 days and then added zeolite $(1 \mathrm{mg} / \mathrm{L})$ for 45 days. The fourth group was exposed to a dose of $(50 \mu \mathrm{g} / \mathrm{L})$ cadmium chloride for 45 days and then added zeolite $(5 \mathrm{mg} / \mathrm{L})$ for 45 days, the fifth group was exposed to a dose of $(50 \mu \mathrm{g} / \mathrm{L})$ cadmium chloride plus $(1 \mathrm{mg} / \mathrm{L})$ zeolite for 45 days. The sixth group was exposed to a dose of $(50 \mu \mathrm{g} / \mathrm{L})$ cadmium chloride plus $(5 \mathrm{mg} / \mathrm{L})$ zeolite for 45 days. After the experimental periods, the crayfish were weighted and hemolymph was collected to measure the biochemical parameters (Glucose, total protein, albumin, globulin, A/G ratio, cholesterol, triglyceride, LDL, HDL, $\mathrm{Na}+\mathrm{K}+, \mathrm{Cu}+2$, $\mathrm{Ca}+2$ and $\mathrm{Mg}+2$ ). Results: in $\mathrm{G} 2$ the concentration of total protein, albumin, globulin, HDL, $\mathrm{Na}+\mathrm{K}+, \mathrm{Cu}+2$ and $\mathrm{Ca}+2$ were significantly decreased $(\mathrm{p}<0.05)$ compared with the control group, while glucose, A/G ratio, cholesterol, triglyceride, LDL and $\mathrm{Mg}+2$ were significantly increased $(\mathrm{p}<0.05)$ compared with the control group. The addition of the ion-exchanging agent, zeolite $(1 \mathrm{mg} / \mathrm{L}$ and $5 \mathrm{mg} / \mathrm{L})$ to cadmium exposed group (G2) caused improvement in weight and all hemolymph biochemical parameters in G3, G4, G5 and G6. Conclusion: the synthetic zeolite was able to protect crayfish against cadmium toxicity by reducing the transfer of cadmium from polluted water into crayfish tissue and reducing the chance for metal uptake by interacting in the experimental medium which in evidently improves the physiological and biochemical functions.
\end{abstract}

Keywords: Cadmium, Synthetic Zeolite, Crayfish (Procambarus Clarkii).

\section{INTRODUCTION}

Pollution of the aquatic environments with heavy metals has become a serious concern during the recent years. With the rapid development of various industries, wastes containing metals directly or indirectly discharged into the environment, especially in developing countries and these wastes having brought serious environmental pollution and threatened bio life ${ }^{(\mathbf{1})}$. Furthermore, the impetuous economic and social development of human communities has induced an accelerated environmental change deeply disturbing the natural balance of the compensatory processes in the biosphere ${ }^{(2)}$. The problems of protecting and improving the environment on a planetary scale is one of the most acute and complex contemporary problems. Interrelations of the environment with the economic fields and all sides of social life lead to a mutual conditioning ${ }^{(3)}$. Cadmium $(\mathrm{Cd})$ is considered as one of the most toxic heavy metals and an environmental pollutant toxic to a number of tissues ${ }^{(1)}$.
The persistence and ubiquitous nature of $\mathrm{Cd}$ is coupled with their tendency to accumulate in organisms ultimately produce toxic reactions in aquatic biota, especially in fish. Thus, the deleterious effects of metals on aquatic ecosystems necessitate the continuous monitoring of their accumulation in key species, since it affords indication of temporal and spatial extent of the process and impact on organism's health ${ }^{(4)}$. Removing heavy metals from the aquatic pollution required high energy or special operational requirements. Several techniques such as adsorption, extraction, disambiguation, clotting, ion-exchange, and membrane processes are supposed for the handling of wastewater pollution ${ }^{(3)}$. Adsorption method forms an appropriate method for wastewater handling because of its cost effectiveness and simplicity among all these methods ${ }^{(5)}$. Zeolites are important minerals of hydrated aluminotectosilicates of alkali and alkaline-earth cations with threedimensional structures of interconnecting channels and large pores, capable of trapping molecules in 
proper conditions ${ }^{(6)}$. Each zeolite species has its own unique crystal structure and, hence, its own set of chemical and physical properties. Also, Zeolite acts as an ion-exchanging agent, it has been mainly used in detergency, aquaculture ponds and nuclear waste effluent treatment, but it also has large potential for other applications in liquid waste treatment. The natural zeolite has been used in the treatment of metabolites ${ }^{(7)}$ and synthetic zeolite in radioactive liquid wastes ${ }^{(8)}$. A variety of zeolites play an important role in the environment and are frequently used as adsorbent materials for the removal of heavy metals. The sorption capacity of these materials can be enhanced when treated using acids and bases ${ }^{(5)}$. Several studies have demonstrated that aquatic invertebrates exhibit various degrees of sensitivity to cadmium toxicity. These invertebrates include the fresh water crayfish, $P$. clarkii. The crayfish are being fished commercially for consumption without adequate protection to human health. They constitute a commercially valuable natural renewable resource. Also, they live in a wide range of environmental conditions that include highly polluted waters resulting in high resistance to heavy metals ${ }^{(9)}$. Heavy metals accumulation has been studied in crayfish (10). Crayfish have the ability to bioaccumulate heavy metals while simultaneously excreting it (11). Hence, the main target of this investigation is evaluating the effects of synthetic zeolite on physiological and biochemical parameters after and with cadmium toxicity in freshwater Crayfish (P. clarkii).

\section{MATERIALS AND METHODS}

Experimental design: The red swamp crayfish, $P$. clarkii were obtained from the Nile River and transferred to glass aquaria (40x60x 100 $\mathrm{cm}, 100$ liters) for 21 days to be accustomed the room conditions. They were fed once on alternate days throughout the period of the experiments with a diet of trout pellets, carrot and potato. Crayfish weighed and divided in to six groups (36 individuals for each group), G1 (Control group), G2 (exposedto50 $\mu \mathrm{g} / \mathrm{l}$ cadmium for 45days),G3 (exposedto50 $\mu \mathrm{g} / \mathrm{l}$ cadmium for 45 daysand after that add $1 \mathrm{mg} / \mathrm{L}$ zeolite for 45 days), G4 ( exposedto $50 \mu \mathrm{g} / \mathrm{l}$ cadmium for 45 daysand after that add $5 \mathrm{mg} / \mathrm{l}$ zeolite for 45 days), G5 (exposedto50 $\mu \mathrm{g} / \mathrm{L}$ cadmium in addition to $1 \mathrm{mg} / \mathrm{l}$ zeolite for 45 days) and G6 (exposedto50 $\mu \mathrm{g} / \mathrm{l}$ cadmium in addition to $5 \mathrm{mg} / \mathrm{l}$ zeolite for 45 days). Chemical preparation:
Cadmium chloride: The metal salt used in the preparation of the stock solution was $\mathrm{CdCl}_{2}$ (Merck). The stock solutions of $1000 \mathrm{mg} / \mathrm{L}$. were obtained by dissolving the cadmium salt in tap water. The required volume of stock solution was added to the respective experimental aquaria to achieve the desired concentrations of $50 \mu / L$. Synthesized zeolite: Silica extracted from dry rice husk was used as an amorphous silica source for the synthesis of NaY zeolite by the hydrothermal treatment ${ }^{(\mathbf{1 2})}$. The stock solutions of $1000 \mathrm{mg} / \mathrm{L}$. were obtained by dissolving the zeolite in tap water. The required volume of stock solution was added to the respective experimental aquaria to achieve the desired concentrations of $1 \mathrm{mg} / \mathrm{L}$ and $5 \mathrm{mg} / \mathrm{L}$. Biochemical Physiological Analyses: The crayfish of each group were starved for 24 hours, weighed, hemolymph collected for biochemical parameters and sacrificed after each experimental period of 15,30 and 45 days. Hemolymph samples were collected from the base of the second walking legs of crayfish via a 0.1 $\mathrm{mL}$ with hypodermic syringes into open vacutainer collecting tubes. To prevent coagulation the hemolymph samples were immediately transferred to $0^{\circ} \mathrm{C}$ and maintained at this temperature until analysis. Hemolymph samples centrifuged at 3000 rpm for 10 minutes using a cooling centrifuge (IEC Centra-4R, International Equipment Co., USA). The sera were separated at once by micropipette, divided into aliquots and stored at $-70^{\circ} \mathrm{C}$ for biochemical measurements. The biochemical parameters: serum glucose level (mg/dl), total protein (TP) and albumin $(\mathrm{g} / \mathrm{dl})$, Cholesterol $(\mathrm{mg} / \mathrm{dl})$, triglycerides $(\mathrm{mg} / \mathrm{dl})$, HDL-c level (mg/dl), LDL-c level (mg/dl), sodium $(\mathrm{mmol} / \mathrm{l})$, potassium $(\mathrm{mmol} / \mathrm{l}$ calcium level $(\mathrm{mg} / \mathrm{dl})$, magnesium level $(\mathrm{mg} / \mathrm{dl})$ and Serum Copper level $(\mu \mathrm{g} / \mathrm{dl})$ were estimated using Randox diagnostic kits, United Kingdom. Serum globulin concentrations were calculated according to the formula: Globulin $(\mathrm{g} / \mathrm{dl})=$ total protein $(\mathrm{g} / \mathrm{dl})$-albumin $(\mathrm{g} / \mathrm{dl})$, then $\mathrm{A} / \mathrm{G}$ ratio was determined. Statistical analysis: The obtained data were subjected to ANOVA-Tukey test using statistical analysis system SPSS program software. The significance between the means was tested at $\mathrm{p}<0.05$.

\section{RESULTS}

The present study showed that the total weight (Mean $\pm \mathrm{SE}$ ) of $P$. clarkii was significantly decreased $(\mathrm{P}<0.05)$ after treatment with cadmium (G2) compared to the control group (G1). On the 
other hand, the mean weight of crayfish treated with cadmium and adding zeolites later (G3 and G4) or during treated (G5 and in G6) were significantly increased $(\mathrm{P}<0.05)$ compared to cadmium treated group only (Fig.1). Data shown in Fig. (2) explained that the hemolymph glucose concentration of cadmium treated group was significantly increased when compared to the control group. On the other hand, adding zeolite after or with cadmium caused significant decreased compared to cadmium treated group only. The data in Table (1) showed significant decreased in the hemolymph total protein, albumin, globulin and $\mathrm{A} / \mathrm{G}$ ratio values in cadmium treated group after 30 and 45 days compared to control. On the other hand, after adding zeolites to cadmium treated groups, there was significantly increase after 30 and 45 days compared to cadmium treated group but recorded significant decreases after 15 and 30 days compared to control group. While adding zeolites with cadmium treated groups the concentration of total protein, albumin, globulin and A/G ratio was significantly increased when compared to cadmium treated group during the exposure period. Significant increase was observed in the hemolymph of Cholesterol and triglyceride concentration in cadmium treated group when compared to control. On the other hand, after adding zeolites it showed significantly decreased (G3, G4, G5 and G6) as compared to cadmium treated group during the exposure period (Table. 2). As demonstrated in the table (2) the hemolymph HDL concentration significantly decreased $(\mathrm{P}<0.05)$ in cadmium treated group after 30 and 45 days only when compared to control. On the other hand, adding zeolites after or with cadmium treated groups (G3, G4, G5 and G6) caused significantl increased $(\mathrm{P}<0.05)$ after 30 and 45 days compared to cadmium treated groups during the exposure period. In table (2) values of hemolymph LDL concentration in cadmium treated group was higher when compared to control. significant decrease $(\mathrm{P}<0.05)$ was observed in hemolymph LDL concentration after adding zeolite after or with cadmium treated groups (G3, G4, G5 and G6). Table (3) showed that hemolymph sodium and potassium concentration in cadmium treated group was significantly decreased $(\mathrm{P}<0.05)$ compared to the control group. On the other hand, hemolymph sodium and potassium concentration after adding zeolites significantly increased $(\mathrm{P}<0.05)$ as compared to cadmium treated group. As shown in table (3) there was a significant increase $(\mathrm{P}<0.05)$ in hemolymph magnesium and copper concentration after 15, 30 and 45 days of exposure to cadmium (G2). On the other hand, the hemolymph magnesium concentration decreased compared to cadmium treated groupafter 30 and 45 day. Moreover, adding zeolites with cadmium treated groups (G5and G6) was a significant decrease $(\mathrm{P}<0.05)$ hemolymph magnesium concentration when compared to cadmium treated group during the exposure period. Hemolymph calcium concentration in cadmium treated group was significantly decreased $(\mathrm{P}<0.05)$ compared with the control group after 30 and 45 days only. On the other hand, adding $(1 \mathrm{mg} / \mathrm{l})$ zeolite to the cadmium treated group (G3),showed significant increase in calcium concentration compared to cadmium treated group (G2) after 45 days only. Also, after adding ( $5 \mathrm{mg} / \mathrm{l})$ zeolite to the cadmium treated group (G4), there was significant increase $(\mathrm{P}<0.05)$ in calcium concentration after 30 and 45 days when compared to cadmium treated group.

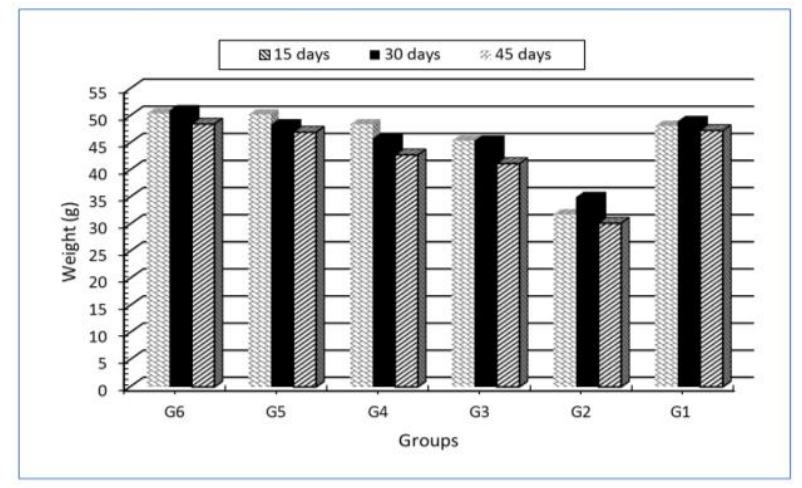

Figure 1: Changes in weights of crayfish $(P$. clarkii) exposed to cadmium toxicity and treatment by synthetic zeolite after 15,30 and 45 days.

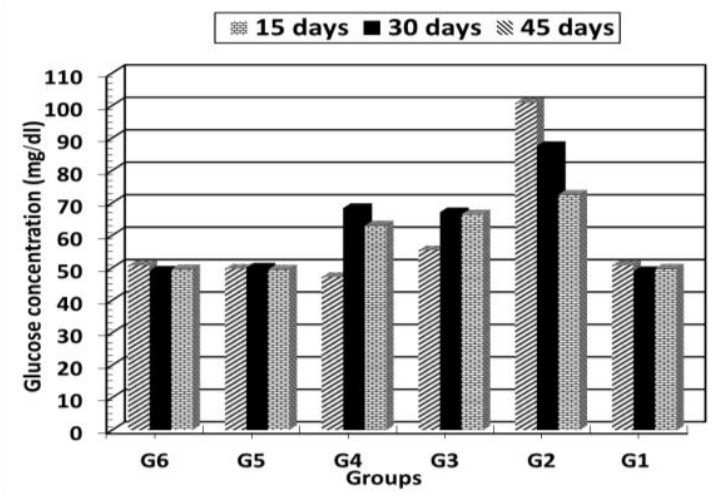

Figure 2: Changes in glucose concentrations $(\mathrm{mg} / \mathrm{dl})$ in hemolymph of crayfish ( $P$. clarkii) exposed to cadmium toxicity and treatment by synthetic zeolite after 15, 30 and 45 days. 
Mohamed M.A. Shahat et al.

Table (1): Changes in total proteins (g/dl), albumin (g/dl), globulin (g/dl) and A/G ratio in hemolymph of crayfish (P. clarkii) exposed to cadmium toxicity and treatment by synthetic zeolite after 15,30 and 45 days.

\begin{tabular}{|c|c|c|c|c|c|c|c|}
\hline Parameters & Groups & G1 & G2 & G3 & G4 & G5 & G6 \\
\hline \multirow{3}{*}{ Total protein $(\mathbf{g} / \mathbf{d l})$} & 15 days & $5.980 \pm 0.077$ & $5.820 \pm 0.150$ & $4.080 \pm 0.042^{*}$ & $3.970 \pm 0.191^{*}$ & $5.960 \pm 0.073^{\mathrm{A}}$ & $5.870 \pm 0.158^{\mathrm{A}}$ \\
\hline & 30 days & $5.990 \pm 0.072$ & $4.010 \pm 0.031^{*}$ & $4.590 \pm 0.034^{* \mathrm{~A}}$ & $4.760 \pm 0.102^{* \mathrm{~A}}$ & $5.940 \pm 0.035^{\mathrm{A}}$ & $5.830 \pm 0.139^{\mathrm{A}}$ \\
\hline & 45 days & $5.970 \pm 0.065$ & $3.170 \pm 0.007^{*}$ & $5.410 \pm 0.006^{\mathrm{A}}$ & $5.840 \pm 0.041^{\mathrm{A}}$ & $5.930 \pm 0.135^{\mathrm{A}}$ & $5.970 \pm .072^{\mathrm{A}}$ \\
\hline \multirow{3}{*}{ Albumin (g/dl) } & 15 days & $1.960 \pm 0.101$ & $1.890 \pm 0.024$ & $1.690 \pm 0.051$ & $1.740 \pm 0.059$ & $1.950 \pm 0.029^{\mathrm{A}}$ & $1.940 \pm 0.024^{\mathrm{A}}$ \\
\hline & 30 days & $1.930 \pm 0.111$ & $1.250 \pm 0.055^{*}$ & $1.770 \pm 0.003^{\mathrm{A}}$ & $1.770 \pm 0.041^{\mathrm{A}}$ & $1.940 \pm 0.020^{\mathrm{A}}$ & $1.900 \pm 0.021^{\mathrm{A}}$ \\
\hline & 45 days & $1.910 \pm 0.108$ & $1.230 \pm 0.010^{*}$ & $1.860 \pm 0.038^{\mathrm{A}}$ & $1.930 \pm 0.034^{\mathrm{A}}$ & $1.900 \pm 0.017^{\mathrm{A}}$ & $1.910 \pm 0.024^{\mathrm{A}}$ \\
\hline \multirow{3}{*}{ Globulin (g/dl) } & 15 days & $4.020 \pm 0.177$ & $3.930 \pm 0.135$ & $2.390 \pm 0.012^{*}$ & $2.230 \pm 0.141^{*}$ & $4.010 \pm 0.102$ & $3.930 \pm 0.164^{\mathrm{A}}$ \\
\hline & 30 days & $4.060 \pm 0.142$ & $2.360 \pm 0.086^{*}$ & $2.820 \pm 0.036^{* \mathrm{~A}}$ & $2.790 \pm 0.092^{* \mathrm{~A}}$ & $4.00 \pm 0.020^{\mathrm{A}}$ & $3.930 \pm 0.152^{\mathrm{A}}$ \\
\hline & 45 days & $4.060 \pm 0.174$ & $1.940 \pm 0.017^{*}$ & $3.550 \pm 0.033^{\mathrm{A}}$ & $3.910 \pm 0.050^{\mathrm{A}}$ & $4.030 \pm 0.140^{\mathrm{A}}$ & $4.060 \pm 0.050^{\mathrm{A}}$ \\
\hline \multirow{3}{*}{ A/G ratio: } & 15 days & $0.475 \pm 0.054$ & $0.499 \pm 0.035$ & $0.501 \pm 0.023^{*}$ & $0.511 \pm 0.023^{*}$ & $0.486 \pm 0.021^{\mathrm{A}}$ & $0.494 \pm 0.020^{\mathrm{A}}$ \\
\hline & 30 days & $0.460 \pm 0.044$ & $0.597 \pm 0.017^{*}$ & $0.512 \pm 0.009^{* \mathrm{~A}}$ & $0.511 \pm 0.020^{* \mathrm{~A}}$ & $0.485 \pm 0.003^{\mathrm{A}}$ & $0.483 \pm 0.025^{\mathrm{A}}$ \\
\hline & 45 days & $0.470 \pm 0.043$ & $0.634 \pm 0.010^{*}$ & $0.523 \pm 0.015^{\mathrm{A}}$ & $0.494 \pm 0.014^{\mathrm{A}}$ & $0.471 \pm 0.024^{\mathrm{A}}$ & $0.470 \pm 0.003^{\mathrm{A}}$ \\
\hline
\end{tabular}

Each value represents the mean $\pm \mathrm{SE}$ (standard error).

$*=$ Significant difference from the control groups $(\mathrm{G} 1)(\mathrm{P}<0.05)$

$\mathrm{A}=$ Significant difference from treated groups with cadmium $(\mathrm{G} 2)(\mathrm{P}<0.05)$ 
Table (2): Changes in Cholesterol (mg/dl), Triglyceride (mg/dl), HDL-c level (mg/dl) and LDL-c level (mg/dl) in hemolymph of crayfish $(P$. clarkii) exposed to cadmium toxicity and treatment by synthetic zeolite after 15, 30 and 45 days.

\begin{tabular}{|c|c|c|c|c|c|c|c|}
\hline Parameters & $\begin{array}{l}\text { Groups } \\
\text { Periods }\end{array}$ & G1 & G2 & G3 & G4 & G5 & G6 \\
\hline \multirow{3}{*}{ 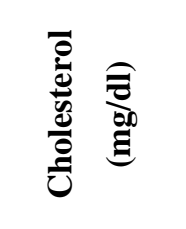 } & 15 days & $138.90 \pm 1.285$ & $177.91 \pm 1.221^{* \mathrm{~A}}$ & $161.91 \pm 1.221^{* \mathrm{~A}}$ & $165.83 \pm 2.270^{* \mathrm{~A}}$ & $135.77 \pm 4.517^{\mathrm{A}}$ & $138.91 \pm 0.781^{\mathrm{A}}$ \\
\hline & 30 days & $140.90 \pm 1.285$ & $187.20 \pm 1.799^{* \mathrm{~A}}$ & $167.20 \pm 1.790^{* \mathrm{~A}}$ & $157.31 \pm 1.507^{* \mathrm{~A}}$ & $138.40 \pm 1.509^{\mathrm{A}}$ & $139.53 \pm 1.596^{\mathrm{A}}$ \\
\hline & 45 days & $138.99 \pm 1.285$ & $190.43 \pm 1.779^{*}$ & $144.20 \pm 1.371$ & $139.13 \pm 0.417^{\mathrm{A}}$ & $135.77 \pm 1.198^{\mathrm{A}}$ & $137.20 \pm 0.158^{\mathrm{A}}$ \\
\hline \multirow{3}{*}{ 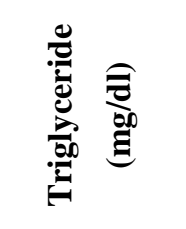 } & 15 days & $116.30 \pm 1.319$ & $161.83 \pm 3.284^{*}$ & $150.19 \pm 0.981^{* \mathrm{~A}}$ & $149.73 \pm 1.618^{* \mathrm{~A}}$ & $116.16 \pm 0.809^{\mathrm{A}}$ & $114.52 \pm 1.551^{\mathrm{A}}$ \\
\hline & 30 days & $115.70 \pm 1.419$ & $169.18 \pm 1.610^{*}$ & $141.86 \pm 1.794^{* \mathrm{~A}}$ & $132.88 \pm 1.069^{* \mathrm{~A}}$ & $113.33 \pm 1.827^{\mathrm{A}}$ & $115.53 \pm 0.906^{\mathrm{A}}$ \\
\hline & 45 days & $116.90 \pm 1.112$ & $177.97 \pm 1.695^{*}$ & $123.83 \pm 0.906^{\mathrm{A}}$ & $119.81 \pm 1.851^{\mathrm{A}}$ & $116.30 \pm 2.476^{\mathrm{A}}$ & $115.50 \pm 1.735^{\mathrm{A}}$ \\
\hline \multirow{3}{*}{ 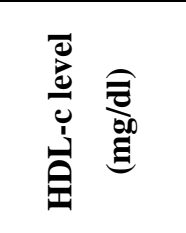 } & 15 days & $56.00 \pm 1.442$ & $49.13 \pm 1.702$ & $44.70 \pm 1.154$ & $46.60 \pm 0.832$ & $55.47 \pm 0.657^{\mathrm{A}}$ & $56.70 \pm 1.155^{\mathrm{A}}$ \\
\hline & 30 days & $57.40 \pm 0.578$ & $41.16 \pm 1.442^{*}$ & $50.33 \pm 1.241^{\mathrm{A}}$ & $51.83 \pm 1.036^{\mathrm{A}}$ & $55.50 \pm 0.908^{\mathrm{A}}$ & $56.67 \pm 0.611^{\mathrm{A}}$ \\
\hline & 45 days & $56.70 \pm 1.112$ & $34.17 \pm 0.938^{*}$ & $52.37 \pm 1.572^{\mathrm{A}}$ & $55.73 \pm 2.073^{\mathrm{A}}$ & $55.51 \pm 0.451^{\mathrm{A}}$ & $55.77 \pm 0.751^{\mathrm{A}}$ \\
\hline \multirow{3}{*}{ 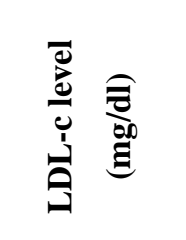 } & 15 days & $67.45 \pm 1.747$ & $84.20 \pm 2.299^{*}$ & $70.10 \pm 1.179^{\mathrm{A}}$ & $71.37 \pm 1.146^{\mathrm{A}}$ & $69.20 \pm 1.322^{\mathrm{A}}$ & $66.43 \pm 1.703^{\mathrm{A}}$ \\
\hline & 30 days & $66.44 \pm 1.748$ & $84.63 \pm 1.480^{*}$ & $72.26 \pm 1.244^{\mathrm{A}}$ & $70.33 \pm 0.742^{\mathrm{A}}$ & $68.60 \pm 2.639^{\mathrm{A}}$ & $69.40 \pm 1.778^{\mathrm{A}}$ \\
\hline & 45 days & $65.44 \pm 1.356$ & $92.20 \pm 2.205^{*}$ & $68.63 \pm 0.296^{\mathrm{A}}$ & $65.33 \pm 1.041^{\mathrm{A}}$ & $66.53 \pm 0.780^{\mathrm{A}}$ & $66.63 \pm 1.670^{\mathrm{A}}$ \\
\hline
\end{tabular}

Each value represents the mean $\pm \mathrm{SE}$ (standard error).

$*=$ Significant difference from the control groups $(\mathrm{G} 1)(\mathrm{P}<0.05)$

$\mathrm{A}=$ Significant difference from treated groups with cadmium $(\mathrm{G} 2)(\mathrm{P}<0.05)$ 
Mohamed M.A. Shahat et al.

Table (3): Changes in sodium (Mmol/l), potassium (Mmol/l), magnesium $(\mathrm{mg} / \mathrm{dl})$, copper $(\mu \mathrm{g} / \mathrm{dl})$ and calcium $(\mathrm{mg} / \mathrm{dl})$ in hemolymph of crayfish $(P$. clarkii) exposed to cadmium toxicity and treatment by synthetic zeolite after 15, 30 and 45 days.

\begin{tabular}{|c|c|c|c|c|c|c|c|}
\hline & & G1 & G2 & G3 & G4 & G5 & G6 \\
\hline \multirow{3}{*}{ 声 } & 15 days & $163.70 \pm 0.420$ & $146.00 \pm 1.114^{*}$ & $135.71 \pm 2.867^{* \mathrm{~A}}$ & $136.05 \pm 1.787^{* \mathrm{~A}}$ & $161.64 \pm 1.320^{\mathrm{A}}$ & $163.53 \pm 1.420^{\mathrm{A}}$ \\
\hline & 30 days & $163.87 \pm 0.530$ & $139.33 \pm 2.194^{*}$ & $151.53 \pm 1.049^{* \mathrm{~A}}$ & $148.57 \pm 0.875^{* \mathrm{~A}}$ & $162.34 \pm 2.019^{\mathrm{A}}$ & $162.43 \pm 2.206^{\mathrm{A}}$ \\
\hline & 45 days & $164.71 \pm 0.210$ & $124.47 \pm 1.514^{*}$ & $160.46 \pm 1.472^{\mathrm{A}}$ & $163.22 \pm 1.238^{\mathrm{A}}$ & $162.11 \pm 2.011^{\mathrm{A}}$ & $163.19 \pm 1.040^{\mathrm{A}}$ \\
\hline \multirow{3}{*}{ 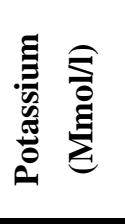 } & 15 days & $8.99 \pm 0.200$ & $7.22 \pm 0.030^{*}$ & $5.55 \pm 0.276^{*}$ & $5.56 \pm 0.238^{*}$ & $8.20 \pm 0.208^{A}$ & $8.61 \pm 0.055^{\mathrm{A}}$ \\
\hline & 30 days & $8.76 \pm 0.211$ & $6.17 \pm 0.100^{*}$ & $6.33 \pm 0.167^{* \mathrm{~A}}$ & $6.62 \pm 0.232^{* A}$ & $8.62 \pm 0.240^{\mathrm{A}}$ & $8.60 \pm 0.260^{\mathrm{A}}$ \\
\hline & 45 days & $8.64 \pm 0.201$ & $5.08 \pm 0.119^{*}$ & $7.78 \pm 0.174^{\mathrm{A}}$ & $8.37 \pm 0.175^{\mathrm{A}}$ & $8.41 \pm 0.382^{\mathrm{A}}$ & $8.53 \pm 0.200^{\mathrm{A}}$ \\
\hline \multirow{3}{*}{ 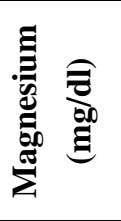 } & 15 days & $2.22 \pm 0.122$ & $2.85 \pm 0.064^{*}$ & $3.31 \pm 0.049^{*}$ & $3.37 \pm 0.125^{*}$ & $2.16 \pm 0.070^{\mathrm{A}}$ & $2.14 \pm 0.013^{\mathrm{A}}$ \\
\hline & 30 days & $2.19 \pm 0.138$ & $3.11 \pm 0.047^{*}$ & $2.78 \pm 0.105^{* A}$ & $2.74 \pm 0.130^{* \mathrm{~A}}$ & $2.11 \pm 0.067^{\mathrm{A}}$ & $2.15 \pm 0.123^{\mathrm{A}}$ \\
\hline & 45 days & $2.23 \pm 0.140$ & $3.48 \pm 0.104^{*}$ & $2.15 \pm 0.038^{\mathrm{A}}$ & $2.08 \pm 0.050^{\mathrm{A}}$ & $2.19 \pm 0.182^{\mathrm{A}}$ & $2.16 \pm 0.123^{\mathrm{A}}$ \\
\hline \multirow{3}{*}{ 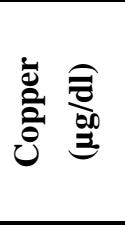 } & 15 days & $4.11 \pm 0.071$ & $4.06 \pm 0.111$ & $3.89 \pm 0.047$ & $3.87 \pm 0.200$ & $3.98 \pm 0.012^{\mathrm{A}}$ & $4.11 \pm 0.013^{\mathrm{A}}$ \\
\hline & 30 days & $4.11 \pm 0.061$ & $3.13 \pm 0.109^{*}$ & $3.88 \pm 0.222^{\mathrm{A}}$ & $3.91 \pm 0.122^{\mathrm{A}}$ & $4.03 \pm 0.104^{\mathrm{A}}$ & $4.11 \pm 0.096^{\mathrm{A}}$ \\
\hline & 45 days & $4.17 \pm 0.052$ & $3.08 \pm 0.054^{*}$ & $4.02 \pm 0.061^{\mathrm{A}}$ & $4.02 \pm 0.174^{\mathrm{A}}$ & $4.11 \pm 0.123^{\mathrm{A}}$ & $4.14 \pm 0.220^{\mathrm{A}}$ \\
\hline \multirow{3}{*}{ 言 } & 15 days & $34.47 \pm 1.570$ & $30.73 \pm 0.464$ & $22.07 \pm 0.896^{*}$ & $27.56 \pm 0.520$ & $34.43 \pm 0.644^{\mathrm{A}}$ & $33.99 \pm 0.496^{\mathrm{A}}$ \\
\hline & 30 days & $34.49 \pm 1.500$ & $23.97 \pm 0.578^{*}$ & $25.57 \pm 0.933^{*}$ & $30.34 \pm 0.730^{\mathrm{A}}$ & $33.00 \pm 0.379^{\mathrm{A}}$ & $34.63 \pm 0.320^{\mathrm{A}}$ \\
\hline & 45 days & $35.40 \pm 1.370$ & $20.50 \pm 0.473^{*}$ & $29.56 \pm 0.751^{\mathrm{A}}$ & $34.81 \pm 1.093^{\mathrm{A}}$ & $34.00 \pm 1.162^{\mathrm{A}}$ & $34.32 \pm 1.193^{\mathrm{A}}$ \\
\hline
\end{tabular}

Each value represents the mean \pm SE (standard error).

*= Significant difference from the control groups $(\mathrm{G} 1)(\mathrm{P}<0.05)$

$\mathrm{A}=$ Significant difference from treated groups with cadmium $(\mathrm{G} 2)(\mathrm{P}<0.05)$ 


\section{DISCUSSION}

Cadmium is one of many metals that are not physiologically or biochemically essential to organisms. This element is extremely dangerous as it is easily absorbed and remains in tissues for a long time. Long exposure to high or low doses of cadmium may cause biochemical and functional changes in some critical organs ${ }^{(\mathbf{1 3})}$. The present results demonstrated that cadmium, particularly with its lower concentration, showed considerably negative effects on $P$. clarkii resulting in significant reduction in body weight in cadmium treated group (G2), this conclusion is consistent with the results of previous reports. For example, growth reduction has been observed in hemimetabolous Aiolopus thalassinus, Orchesella cincta, Oncopeltu fasciatus $^{(\mathbf{1 3 )}}$ and holometabolous insects Lymantria dispar, Chironomus riparius, Poecilus cupreus $^{(\mathbf{1 4})}$. Many studies have shown that the growth rate is lower in fish exposed to mixtures of metals through alterations of enzymatic capacity and in some situations, alterations of the food basis in contaminated waters ${ }^{(\mathbf{1 5})}$. Furthermore, it has shown that cadmium decreases food intake and assimilation and this may lead to the reduction in the growth rate in fish ${ }^{(16)}$. Blood glucose is a sensitive reliable indicator of environmental stress. In the present study, cadmium elevated glucose level in crayfish with a comparison to control group. Our results agree with previous reports suggested that hyperglycemia occurred after toxicity with cadmium, it may be due to change in liver carbohydrate metabolism as in some marine and freshwater fish species ${ }^{(17)}$ and in the crayfish $P$. clarkii $^{(\mathbf{1 8 )}}$. Machale et al. ${ }^{\left({ }^{(19)}\right.}$ reported that cadmium exposure, as in fishes, induces hyperglycemia in the freshwater prawn, Macrobrachium kistnensis, and the crab, Barytelphusa cuniculeris. The medulla terminalis $\mathrm{X}$-organ-sinus gland complex in the eyestalk is the source of the crustacean hyperglycemic hormone $(\mathrm{CHH})$, which regulates the blood glucose levels. Recent studies provided evidence for the involvement of $\mathrm{CHH}$ in cadmiuminduced hyperglycemia in P.clarkii ${ }^{(\mathbf{2 0})}$. Total protein level is a frequent parameter of metal poisoning in fish and one of the important functions of serum protein is maintenance of osmotic balance between the circulating blood and the tissue fluids ${ }^{(20)}$. The represented data showed significantly decrease after 30 and 45 days in the hemolymph total protein, albumin, globulin and $\mathrm{A} / \mathrm{G}$ ratio values in cadmium treated group as compared to the control group. These results were in agreement with previous reports examined the effects of cadmium or other heavy metal exposure on invertebrates or other, such as $P$. clarkii $^{(\mathbf{2 1})}$;Penaeus indicu ${ }^{(25)}$ and $O$. niloticus ${ }^{(22)}$. Also, Prabu et al. ${ }^{(20)}$ recorded that plasma total protein, albumin and globulin decreased in cadmium exposed animal. The decreases in total protein may be due to several pathological processes induced by heavy metals including plasma dissolution, renal damage and protein elimination in the urine, a decrease in liver protein synthesis, and alteration in hepatic blood flow and/or hemorrhage into the peritoneal cavity and intestine and RNA content in the liver ${ }^{(23)}$. Also, the decrease in protein content is probably due to enzyme inhibition which plays an important role in protein synthesis (24). Lipids because of their rapid metabolic transformation are considered as a transient body material, but they represent the major source of stored chemical energy and their absence reflects the physiological capacity of fish. The liver is regarded as one of the central metabolic organs in the body, regulating and maintaining lipid homeostasis (25). The present results, in cadmium exposed clarikii showed an increase in cholesterol, triglycerides and LDL. While decreased in the level of HDL compared to the control group. These results in agreement with previous reports examined the effects of cadmium or other heavy metal exposure on other organisms. Regarding the level of cholesterol recorded a significant increase in rats treated with cadmium chloride ${ }^{(26)}$. Alterations in lipid profile and total cholesterol were observed in cadmium administered animals ${ }^{(27)}$. On other hand, Shin et al. ${ }^{(28)}$ found a significant decrease of triglycerides values in the butterflies Galleria mellonella exposed to cadmium chloride at different concentrations compared with non-exposed control groups. The elevated levels of LDL followed by the decrease in the level of HDL were noticed in cadmium administered rats. This might be due to the impairment of liver function caused by the imbalance in antioxidant defense system in $\mathrm{Cd}$ intoxicated rats, cadmium toxic condition decreased the production of HDL in liver (29). Cadmium toxicity leads to a variety of derangements in metabolic and regulatory processes in lipids, which in turn leads to dyslipidemia, the most common metabolic complication observed in heavy metal toxicity characterized by distinct 
changes from a normal plasma lipid and lipoprotein profile ${ }^{(30)}$. The present study showed that the exposure of $P$. clarkiito cadmium decreased hemolymph $\mathrm{Na}^{+}, \mathrm{K}^{+}, \mathrm{Ca}^{++}$and $\mathrm{Cu}^{++}$ions and increased $\mathrm{Mg}^{++}$level compared with a control group that agree with previous studies. Cadmium decreased plasma $\mathrm{Na}^{+,} \mathrm{K}^{+} \mathrm{Ca}^{++}$ions but increased $\mathrm{Mg}^{++}$level in Salmo gairdneri and Cyprinus carpio $^{(28)}$. Cadmium caused an increase in the plasma $\mathrm{Mg}^{++}$and inorganic phosphate level, however, a decrease in $\mathrm{K}^{+}$and $\mathrm{Ca}^{++}$level. The alteration in the ion equilibrium, especially the significant decrease in plasma $\mathrm{K}^{+}$and $\mathrm{Ca}^{++}$levels were explained by pathological alterations in the tissues related to ion regulation. Similarly, the decrease in the $\mathrm{Ca}^{++}$level was followed by the increase in the $\mathrm{Mg}^{++}$level which was influenced by cadmium ${ }^{(4)}$. In the fish Oreochromis mossambicus, plasma $\mathrm{Ca}^{++}$and $\mathrm{Na}^{+}$levels decreased even in very low cadmium concentrations ${ }^{(27)}$. Although calcium loss subsequent to cadmium exposure is commonly reported in fish Oncorhynchusmykiss ${ }^{(26)}$. Serum calcium levels showed a significant decrease in treated groups of rats after 6-12 weeks of exposure to cadmium chloride ${ }^{(29)}$. The increase in the serum $\mathrm{Mg}^{++}$level is interpreted as the indirect consequence of the decrease in $\mathrm{Ca}^{++}$level and $\mathrm{Na}^{+}$loss following cadmium exposure. It has been suggested that cadmium enters mainly through the chloride cells in the fish gill, via the same uptake mechanisms as calcium, such as $\mathrm{Ca}^{2+}$ channels, $\mathrm{A}^{+} / \mathrm{Ca}^{2+}$ exchangers or $\mathrm{Ca}^{2+}$ ATPase. Thus, a cadmium-induced inhibition of $\mathrm{Ca}^{2+}$ influx has been linked to competition at the apical uptake channels ${ }^{(29)}$. According to McGeer et al. ${ }^{(30)}$ cadmium exposure conducts to a depletion of $\mathrm{Ca}^{2+}$ which can ultimately lead to death. Also, cadmium induced renal tubular dysfunction leads to increased urinary excretion of calcium. The concentration of copper reduced after exposure to cadmium. The present study showed that the addition of synthetic zeolite to cadmium contaminated media (in groups 3, 4, 5 and 6) increase the body weight, this is more pronounced in G3 and G4. These results agree with previous studies, zeolites added to food have been shown to increase the body weight and haemoglobin contents in cattle ${ }^{(8)}$. Also, Wang and Peng ${ }^{(6)}$ reported that the element in the molecular sieve of zeolites is exchanged with metal ion thus the concentration of metal is decreased in the exposure water; as a result, deleterious effects in the tissues are reduced. Among the various cation exchangers, zeolites are preferred due to its high specificity for heavy metal cations, thus the synthetic zeolite is useful and can be used for attenuation of cadmium toxicity and enhance the body weight in crayfish. Our results recorded in table 1,2 and 3, and figure 1and 2 showed that addition of ion-exchanging agent, zeolite after or with treated groups with cadmium (G3, G4, G5 and G6) reduces the cadmium concentration in crayfish tissue, reduce their toxicity and improve biochemical parameters especially Glucose, total protein, albumin, globulin, A/G ratio, cholesterol, triglyceride, LDL, $\mathrm{Na}^{+}, \mathrm{K}^{+}, \mathrm{Cu}^{2+}, \mathrm{Ca}^{2+}$ and $\mathrm{Mg}^{2+}$ respectively. However, there were reports on the effects of zeolites on serum biochemistry (health) parameters which are parallel with the present results on hemolymph parameters, for serum $\mathrm{Ca}^{2+}$, for serum triglyceride; serum HDL, LDL levels, cholesterol and glucose levels ${ }^{(8)}$. Eleroglu et al. ${ }^{(7)}$ reported that zeolite affects on the reduction of cadmium level in water and improvement of hematological parameters in Oreochromis mossambicus. Noori et al. ${ }^{(9)}$ reported that application of synthetic zeolite results in the immobilization of heavy metals and recommended for the cleanup method. In aquaculture practices, application of low cost ion-exchanging agent zeolite in ponds before stocking fry or during the pond preparation is suggested. In the present study, even the maximum dose of $5 \mathrm{mg} / \mathrm{l}$ did not produce any adverse effects on crayfish. Comparatively, zeolite causes no side effects and more suitable than EDTA and NTA and hence it may be considered as the best chemical agent to remove toxic elements from polluted environments ${ }^{(30)}$.

\section{CONFLICTS OF INTEREST}

There are no conflicts of interest.

\section{REFERENCES}

1. Al-Asgah NA, Abdel-Warith AA, Younis
EM and Allam HY (2015):
"Haematological and biochemical
parameters and tissue accumulations of
cadmium in Oreochromis niloticus
exposed to various concentrations of
cadmium chloride." Saudi Journal of
Biological Sciences,22:543-550


2. Balan L, Tipa S, Doval E and Micu D (2010): "Environmental pollution and human health." Metalurg. Intern., 15 (9): 56-60.

3. Petrescu DC, Bran F and Petrescu-Mag RM (2010): "The water footprint and its impact on sustainable water consumption." Metalurgia Int., 15(1): 8186.

4. Okocha RC and Adedeji OB (2011): "Overview of cadmium toxicity in fish." J. Applied Sci. Res., 7: 1195-1207.

5. Taamneh Y and Sharadqah S (2017): “The removal of heavy metals from aqueous solution using natural ordanian zeolite." Appl Water Sci.,7:2021-2028

6. Wang $S$ and Peng $Y$ (2010): "Natural zeolites as effective adsorbents in water and wastewater treatment." Chem. Eng. J., 156:11-24.

7. Eleroglu $H$, Yalcın $H$ and Yıldırım $A$ (2011): "Dietary effects of Ca-zeolite supplementation on some blood and tibial bone characteristics of broilers." South African Journal of Animal Science, 41 (4): $319-330$

8. Noori M, Zendehdel $M$ and Ahmadi A (2006): "Using natural zeolite for improvement of soil salinity and crop yield." Toxicol. Environ. Chem., 88: 7784.

9. Balarezo A and Tchounwou PB (2010): "Acute toxicity of lead nitrate to red swamp crayfish, Procambarus clarkii." WIT Transactions on Ecology and the Environment,132:101-107

10. White RR, Hardaway C.J, Richert JC, and Sneddon J (2012): "Selenium-lead interactions in crayfish (Procambrus clarkii) in a controlled laboratory environment." Microchemical Journal, 102: 91-114.
11. Alcorlo P, Otero M, Crehuet M, Baltanas $A$ and Montes C (2006): "The use of the red swamp crayfish (Procambarus clarkii) as indicator of the bioavailability of heavy metals in environmental monitoring in the River Guadiamar (SW, Spain)." Science of the Total Environment, 366: 380-399.

12. Ruren XU, Pang W, Yu J, Huo $Q$ and Chen J (2007): "Chemistry of Zeolites and Related Porous Materials: Synthesis and Structure" John Wiley \& Sons (Asia) Pte Ltd 2 Clementi Loop Singapore 129809.

13. Cervera A, Maymo AC, Sendra M, Martínez-Pardo $R$ and Garcera MD (2004): "Cadmium effects on development and reproduction of Oncopeltus fasciatus (Heteroptera: Lygaeidae).” J. Ins. Physiol., 50: 737749.

14. Maryaski M, Kramarz P, Laskowski $\mathbf{R}$ and Nikliska $M$ (2002): "Decreased energetic reserves, morphological changes and accumulation of metals in carabid beetles (Poecilus cupreus L.) exposed to zinc-or cadmiumcontaminated food." Ecotoxicol., 11: 127 139.

15. Sherwood GD, Rasmussen JB, Rowan DJ, Brodeur J and Hontela A (2000): "Bioenergetic costs of heavy metal exposure in yellow perch (Perca flavescens): in situ estimates with radiotracer (137CS) technique." Can. J. Fish Aquat. Sci., 57:441-450.

16. Hansen JA, Welsh PG, Lipton J, Cacela $D$ and Dailey AD (2002):"Relative sensitivity of bull trout (Salvelinus confluentus) and rainbowtrout (Oncorhynchus mykiss) to acute exposures of cadmium and zinc." Environ Toxicol Chem., 21:67-75. 
17. Mekkawy AA, Mahmoud UM, Wassif ET, Naguib M (2011): "Effects of cadmium on some haematological and biochemical characteristics of Oreochromis niloticus (Linnaeus, 1758) dietary supplemented with tomato paste and vitamin E." Fish Physiol. Biochem., 37:71-84

18. Chinni $S$ and Yallapragada PR (2002): "Energy levels of Penaeus indicus postlarvae on exposure to lead." Ecotoxicol. Environ. Saf., 52: 173-179.

19. Machale PR, Khan AK, Sarojini $R$ and Nagabushanam R (1989): "Copper and cadmium induced changes in blood sugar level of the crab, Barytelphusa cunicularis." Uttar Pradesh J. Zool., 9: 113-115.

20. Prabu SM, Shagirtha K and Renugadevi J (2010): "Amelioration of cadmiuminduced oxidative stress, impairment in lipids and plasma lipoproteins by the combined treatment with quercetin and $\alpha$ tocopherol in rats." J. Food Sci., 75: $132-$ 140.

21. Vinodhini $R$ and Narayanan $M$ (2008): "Effect of heavy metals induced toxicity on metabolic biomarkers in common carp (Cyprinus Carpio L.).” Mj. Int. J. Sci.

22. Thilakarathna SH, Wang Y, Vasantha Rupasinghe HP and Ghanam K (2012): Apple peel flavonoid and triterpeneenriched extracts differentially affect cholesterol homeostasis in hamsters.” J. Funct. Foods. 4: 963-971.

23. Larregle V, Varas SM, Oliveros LB, Martinez LD, Antón R, Marchevsky E, Giménez MS (2008): "Lipid metabolism in liver of rat exposed to cadmium." Food Chem. Toxicol., 46:1786-1792.
24. Leelavinothan $P$ and Ramalingam $R$ (2013): "Protective effect of Tetrahydrocurcumin on plasma lipids and lipoproteins in cadmium intoxicated rats." Int. J. Toxicol. App. Pharmacol., 3(1): 26-32.

25. Olisekodiaka MJ, Igbeneghu CA, Onuegbu AJ, Oduru AO and Lawal R (2012): "Lipid, lipoproteins, total antioxidant status and organ changes in rats administered high doses of cadmium chloride," Med. Princ.Pract., 21:156-159.

26. Chowdhury MJ, Pane EF and Wood CM (2004): "Physiological effects of dietary cadmium acclimation and waterborne cadmium challenge in rainbow trout: respiratory, ionoregulatory, and stress parameters." Comp. Biochem. Physiol., C,139: 163-173.

27. Marcinkiewicz BP, Sawicki B, Brzbska MM and Moniuszko JJ (2003):"Effect of chronic administration of cadmium on the rat thyroid radioimmunological and immunohistochemical studies." Folia Histochem. Cytobiol., 40: 95-96

28. Shin B, Choi R and Lee C (2001): "Effects of Cadmiumon Total Lipid Content and Fatty Acids of the Greater Wax Moth." J. Ecol., 24(6): 349-352.

29. Silvestre F, Trausch $\mathbf{G}$ and Devos $\mathbf{P}$ (2005): "Hyper-osmoregulation capacity of the Chinese mitten crab (Eriocheir sinensis) exposed to cadmium; acclimation during chronic exposure." Comp. Biochem. Physiol., C, 140: 29-37.

30. McGeer JC, Szebedinszky C, McDonald DG and Wood CM (2000): "Effects of chronic sublethal exposure to waterborne $\mathrm{Cu}, \mathrm{Cd}$ or $\mathrm{Zn}$ in rainbow trout. 1. Ionoregulatory disturbance and metabolic costs." Aquat. Toxicol., 50: 231-243. 